\title{
A Comparative Analysis Of Global Pension Tax Arbitrage
}

Faramarz Damanpour, (E-mail: fdamanpour@msn.com), James Madison University Brooks Marshall, (E-mail: marshasb@jmu.edu), James Madison University

\begin{abstract}
In a company with defined benefit plans, pension assets often represent a sizable portfolio of financial assets. The intention is to examine whether pension tax arbitrage has the potential to add value to the sponsoring corporation with secondary benefits to plan participants, through a less volatile pension fund. To implement the arbitrage, it is recommended that the plans shift all assets to bonds. Replacing stocks with bonds reduces the risk of the firm, and the benefit stems from the creation of an additional tax deduction on the payment of interest with no increase in firm risk.
\end{abstract}

\section{INTRODUCTION}

\begin{abstract}
C the early 1980s, Fischer Black and Irwin Tepper developed an arbitrage strategy for companies with defined benefit pension plans. To implement the arbitrage, both papers recommended that the plans shift all assets to bonds. The arbitrage would be created when the company exactly offset the reduced risk in the pension fund with a tax-advantaged move to more risk in either the capital structure [Black 1980] or more risk in the shareholder's personal portfolio [Tepper1981]. This paper focuses on Black's model and asks if its implementation is viable for the global community.
\end{abstract}

Black's model can be presented in two simple steps. First, stocks in the pension fund are sold and bonds are purchased. Replacing stocks with bonds reduces the risk of the firm. Second, the risk reduction through the pension fund is offset in the capital structure by issuing debt and buying back the firm's stock (this is similar to swapping pension fund stocks to corporate stocks). Replacing equity in the capital structure with debt increases financial leverage and increases the firm's risk. If these two transactions are implemented with correct proportions, the risk of the firm is unchanged. The benefit stems from the creation of an additional tax deduction on the payment of interest with no increase in firm risk.

For two decades, the proposed strategy ignited much controversy but had little apparent impact on the asset allocation strategy of defined benefit pension plans [Copeland, et al, 2005]. Since 2000, however, the strategy has begun to receive recognition in the academic literature [Dammon et al 2004, Franks 2000, Gould et al. 2003]. In 2001, the British pharmaceutical retailer, Boots, implemented the arbitrage strategy - selling stocks in its pension fund and replacing these stocks with bonds [Gold and Hudson 2003]. Although stocks are expected to earn more in than bonds in the long run, Boots can realize the greater return by using the extra debt capacity (created through the pension fund transaction) to buy its own stock. In addition to creating an interest tax deduction with no additional risk, the implementation of the arbitrage also has these other potential benefits:

- $\quad$ Lower management fees

- $\quad$ More entrepreneurial incentive, stemming from more debt usage

- $\quad$ Fortified protection of plan participants

It follows that tax arbitrage's growing acceptance in the U.S. and U.K. has potential for implementation by corporations in other countries. 


\section{LITERATURE REVIEW}

The arbitrage strategy for companies with defined benefit plans as developed by Fisher Black (1980) and Irwin Tepper (1981) was based on shifting assets from stocks to bonds. The arbitrage would be created and become beneficial when the company exactly offset the reduced risk in the pension fund with a tax-advantaged move from stock with higher risk to lower risk bond benefiting either capital structure [Black 1980] and/or the shareholder's personal portfolio [Tepper 1981].

The underlying premise for the arbitrage theory is that the performance of pension assets affects corporate cash flows much like corporate assets. While the pension assets are in a trust that technically belongs to the beneficiaries, the corporation is ultimately responsible for making up any deficiencies in the pension plan as illustrated in the recent market cycle. The strong equity market in the late 1990s provided a first hand example of how closely contributions were linked to pension performance, as many firms took a long "holiday" from any contributions. The sharp downturn in early 2000 provided the opposite examples, as pension funds had to increase contributions, just when the firm could least afford them.

Given that defined benefit pension assets affect cash flows much like corporate assets, the next condition is that the equity markets must recognize the returns from pension assets. The stock price of the pension sponsor should increase with strong pension asset performance, and fall when the fund experiences losses. A stream of literature over three decades [Oldfield 1977, Feldstein et al. 1981, Daley 1984, Landsman 1986, Barth et al. 1991, Barth et al 1992, Coronado et al. 2003] supports the idea that the market impounds pension performance.

After the Oldfield (1997) and Feldstein (1981) articles, interest in pension valuation moved to the accounting arena. Accounting questions stemmed from the new measurement standards required by Statement of Financial Accounting Standard No. $87^{1}$, Employers' Accounting for Pensions, researchers started to investigate the usefulness of the information provided. The stream of accounting research [Daley 1984, Landsman 1986, Barth 1991, and Barth et al 1992] continued to find that pension variables had a statistically and economically significant impact on the market capitalization of the firm, whether the measures were assets or liabilities or capitalized flows, such as pension expense.

The findings generally indicate that each dollar of pension assets creates a dollar of market value. In fact, this result is more than would be expected in theory. Since pension contributions are tax deductible, only $\$ 1$ (1-Tax rate) or $\$ 0.6$, assuming a 40 percent tax rate is required to create $\$ 1$ of pension assets. In sum, it appears the market does impound asset value into the valuation of the company's equity - even more value is assigned that would be predicted in theory [Gold et al. 2003]. Similarly, arguments in defense of arbitrage strategy were presented by Franks (2003) and Dammon, Spratt, and Zhang (2004).

With the two major conditions for effective arbitrage being met, firms still have not implemented the strategy. The reason does not appear to be market driven, but instead the actuarial measurement system has promoted holding equities in the pension fund since equities permit a greater return assumption which in turn decreases the measurement of the funding needed to meet the liability [Zion 2001].

Gordon and Jarvis (2003) looked at the U.K. pension plan and arbitrage strategy, and compared the U.K. plan to the U.S. plan, and the UK plan trustees have a key role with significant powers to use in the interests of the plan beneficiaries, which may conflict with the employer interests. Gold and Hudson (2003) investigate arbitrage strategy used by the British Boots, Pharmaceutical retailer, and report that the lower return from bonds forced Boots to increase its contributions to the plan in the future years, the firm ignored the lower annual management cost associated with bonds versus stocks.

Many other reports looked at the OECD pension assets [Financial Economics and Pensions Actuaries 2003], and pension plans in various countries, as listed in the references, but none dealt with the arbitrage strategy in practical aspects. The main contribution of this paper to the current body of literature is to present the practical implications of arbitrage strategy. 


\section{THE STATEMENT OF PURPOSE}

In a company with defined benefit plans, pension assets often represent a sizable portfolio of financial assets. In the U.S., pension assets are about 14 percent of the market capitalization of the firm's stock, with some company's having a much larger proportion. For example, Ford Motor Company's pension assets are over 1.5 times the market value of its stock and General Motors pension assets represent an even greater proportion, with pension assets over two times the market value of its stock. In the U.S., the average asset allocation is about 60 percent stocks and 40 percent bonds, with a growing proportion of stocks allocated to international equities. This paper explores the potential valuation impact of changing the risk profile of the pension fund.

The significance of changing the risk profile of pension assets is reflected in the answers to these questions. Does the risk of the pension fund, and the change in that risk, affect the risk of the company? That is, do the stock and bond markets treat pension assets like traditional corporate assets and is the pension fund of sufficient size to have a meaningful impact? Second, does the tax structure of the specific country permit defined benefit sponsors to implement a tax arbitrage, taking advantage of the differential between the tax treatment of income from pension assets and the tax treatment of income from corporate assets?

The term defined contribution and defined benefit are used in relation to the pension plan's features. In a defined contribution, the amount of the pension you receive is not set in advance. Instead, you and your employer contribute a set amount to the plan, usually as a percentage of earnings. Defined benefit plans, based on OECD/IASB definition (2003), are those where benefits are predefined in relation to the worker's salary and length of employment. Companies that sponsor defined benefit pension plans are faced with two problems: those related to the presence of promises and guarantees and those related to adverse demographic and economic developments. Regardless of whether defined benefit pension plans are funded internally or through a pension fund, these two problems and others, such as investment funding regulations, condition solvency and risk management in occupational pension plans, influence the outcomes.

Increasing life expectancy and population ageing represent a growing cost for final salary and career average salary plans. This is a long term problem and difficult to deal with because it requires either reducing benefits or increasing retirement age. Investment risk, on the other hand, is very much a short-term problem and one that affects all employers that sponsor defined benefit plans, regardless of type. Three years of stock market declines, from 20012003 and current (2005) stagnant market, have dented severely the funding level of defined benefit plans in most OECD countries. In addition, fall in discount rates have raised the level of pension liabilities valued using market principles. According to OECD (2003) report, the fall in funding levels has been particularly dramatic in countries where pension funds invest heavily in equities, such as Canada, Netherlands, Switzerland, the United Kingdom, and the United States. According to one risk rating firm, funding levels are now well below 100 percent in some occupational plans in these countries.

The purpose of this paper is to examine if pension tax arbitrage has the potential to add value to the sponsoring corporation with secondary benefits to plan participants, through a less volatile pension fund. While the arbitrage presents a risk-free gain, the implementation of the arbitrage takes place in a controversial landscape, where retirees are facing inadequate pension assets as described by Harrington (2004) and the accounting system is trying to come to terms with measurement issues, discussed in FAS 132 (revised) and the upcoming ruling by IAS 19. The defined benefit plan is a separate legal entity of corporate sponsor. Corporations select trustees and management team, and may influence the direction of investment policy. At the same time, corporations bear the risk of investments if investments returns miss the target returns. Of course, corporations may benefit from higher than expected investment returns (exceeding target returns) by helping companies to reduce contributions to plans.

In order to address arbitrage strategy and its benefit, 19 countries with some form of occupational pension plan (typically defined benefit (DB) and defined contribution (DC)) were selected for preliminary investigation. After an in-depth review of their corporate pension plans, 12 countries were eliminated because their plans are not defined benefit, do not pre-fund the pension fund, or have the pension plan structured to share risk between the company and the beneficiary. The final 8 countries involved in this study presented with (*) below. 


\begin{tabular}{cccc}
\hline Argentina & Denmark* & Japan* & Sweden \\
Australia & Finland & Mexico & Switzerland \\
Brazil* & France & Netherlands & United Kingdom* \\
Belgium* & Germany & Norway* & United States* \\
Canada* & Italy & South Korea & \\
\hline
\end{tabular}

Second, an attempt has been made to explain in brief, pension plans in each of the selected countries and the rest in Appendix A, and as much as possible, to point out their differences with the United States pension plans policies. Third, an arbitrage model based on Black's proposal, including the treatment of risk and return, is presented. Fourth, a form of country analysis of the tax arbitrage strategy was developed. The tax rate used here is from KPMG International report 2004; the interest rates are selected from various internet-based sources. Within this context, we addressed four questions related to tax arbitrage viability. Finally, the potential benefits for the countries are summarized. A conclusion and recommendations follow.

\section{GLOBAL PENSION PLANS}

An attempt has been made here to briefly describe pension plans for 6 out of 19 selected countries in this study. The six have attributes that meet the basic criteria of tax arbitrage. The remaining pension plans were presented in Appendix A.

\section{United Kingdom Pension Plan Structure}

The U.K. defined benefit (DB) pension plan is very similar to that of the United States. They both have large employer-sponsored plans providing pension benefits defined in relation to employee earnings that are set up under legislation where the employer makes contributions that are invested to cover the cost of benefits accruing and to offset deficits arising. The key similarity between the U.K. and the U.S. is that both have: many large occupational DB plans, standard to provide benefits linked to compensation DB plans, sponsoring employer typically pays balance of cost, and traditional approach to funding is the same, that is, the projected unit discounting liabilities as expected returns on assets. The key differences is that: the U.K. pension vest after two years versus the U.S. five years, and in the U.K. the total accrued pension is indexed to consumer price inflation both in deferment and payment. Another important difference is the fact that the U.K. plan trustees have a key role with significant powers that they are in theory obliged to use in the interests of the plan beneficiaries. They can act in conflict with the employer [Gordon and Jarvis 2003].

A statistical publication by OECD report the total OECD pension assets by member country as follow:

Table 1

Oecd Pension Assets By Member Country (Percentage of GDP Based on 2001)

\begin{tabular}{lllllr}
\hline United States & 75 & United Kingdom & 85 & Netherlands & 113 \\
Japan & 21 & Australia & 62 & Canada & 48 \\
Others Average & 52 & & & \\
\hline
\end{tabular}

Source: Financial Economics and Pension Actuaries: The U.K. Experience, June 2003.

Bear in mind that the size of GDP in the United States is far larger than all other nations including Japan and China. The U.K. pension funds are estimated at approximately $\$ 1.4$ trillion in 2004. Furthermore, as in the United States, unlike most of continental Europe, the U.K. private-sector provision forms a significant supplement to state provision. In the U.K., it accounts for 40 percent of all retirement income and covers 10 million employees. Referring to Russell Mellon CAPS statistics, Gordon and Jarvis (2003) suggest that the U.K. pension plans invest 75 percent in equities and 10 percent in bonds compared with 60 percent in equities and 30 percent in bonds for the United States. 


\section{Japanese Pension Plan Structure}

Unlike U.S. $401 \mathrm{~K}$ plans, contributions to the company plans must be made entirely by employer up to the limit of $¥ 216,000$ per year. If the employer does not have a defined benefit (DB) plan, the contribution limit doubled to $¥ 432,000$ per year. Self-employed individuals may contribute up to $¥ 816,000$ per year to individual plan. Individuals who are not covered by either a DB or DC plan at their company may contribute up to $¥ 180,000$ per year to an individual plan [Investment Company Institute 2001].

Contributions to plans are tax-exempt. Plan administrators select the investment options for company plans. Plans must include at least three investment options from: mutual funds, investment trusts, savings products, government bonds, equities, and insurance products. Real property, real estate, financial futures and commodity futures are not permissible investment options. Individuals who have participated in a plan for more than 10 years are eligible for distributions at age 60. The eligible age for distributions increases on a sliding scale to 65 for individuals who have participated in a plan for less than 10 years. Participants who die or are severely disabled are eligible to receive distributions regardless of their age. Distributions may be made in the form of an annuity or a lump-sum payment. If a participant participates in the plan for less than three years, contributions must be lump sum [Investment Company Institute 2001/2004].

\section{Canadian Pension Plan Structure}

In a defined benefit plan, you are promised a monthly pension income that is determined by a formula, such as a combination of your earnings, job classification and the length of time you worked for the employer. It is generally the employer's responsibility to ensure that sufficient funds are available to pay your pension when you retire. The employer assumes the risk of investing all contributions wisely to guarantee the future value of your pension. In Canada, most large employers offer pension plans to their employees. Sometimes, a number of employers in an industry will participate in a plan together, often in collaboration with a union. You are usually qualified to join within two years of starting continuous employment. Plans can be mandatory or optional.

The defined benefit pension amount depends on your plan's benefit formula. For example, you may receive a pension up to two percent of your earnings fro each year of services. Once you received your pension, the income is taxable. This is because no tax was paid on the funds while you were making contributions. The four defined benefit formulas are [Canada 2004, Nelson 1999]:

1. A flat amount formula, which provides a flat benefit unrelated to earnings or services.

2. A flat percentage of earnings formula, which provides a benefit related to earnings but which does not reflect services.

3. A flat amount per year of service formula, which reflects service but not earnings.

4. A percentage of earnings per year of services formula, which reflects both earnings and service.

\section{The United States Pension Plan Structure}

In the United States the Employee Retirement Income Security Act (ERISA) provides the legal governance for pension plans. The benefits in most traditional defined benefit plans are protected, within certain limitations, by federal insurance provided through the Pension Benefit Guaranty Corporation (PBGC). The structure of plans is typically based on a plan formula that considers such factors as salary and service - for example, 1 percent of average salary for the last 5 years of employment for every year of service with an employer.

\section{Brazilian Pension Plan Structure}

The Brazilian law defines two different types of pension plan: entidades fechadas and abertas de previdencia privada. Entidades fechadas are occupational pension plans, sponsored by corporations and until recently only for organization with more than 100 employees. They are non-profit organization by definition under the Ministry of 
Social security. Entidade aberta de providencia privada are majority profit organizations run by commercial banks and insurance companies.

During 70's and 80's almost all plans were defined benefit plans. Today the pension funds supported by the private sector outnumbers the ones from the government sector, and is in both defines contribution and defined benefits plans. In the private sector, approximately 30 percent are defined benefit plans and 70 percent are defined contribution plans or combination of both. Nearly 40 percent of these plans are only the employer responsible for the funding of the plan [Lopes 1999].

\section{Belgium Pension Plan Structure}

In Belgium, as in most European countries, an individual's total retirement income is decided according to three sources (pillars). The defined benefit plan is known as second pillar, sponsored at the company or sector level for the employees of that company. In Belgium, many employers provide supplementary pension schemes mostly in the form of DB. In total, 40 percent of the working population have occupational pension sponsored by their employers. There is an attempt to expand the scope of DB plans by Belgium government [Wyatt 2005, SAP 2005].

\section{THE MODEL}

The focus in this paper is on the arbitrage proposed by Black. Tepper's model requires changes at the personal level; with Black's proposal the arbitrage is fully implemented at the corporate level. Consider a U.S. corporation that has its pension assets entirely invested in stocks. The corporation is in the 40 percent tax bracket and all its contributions to the pension fund are fully deductible; for example, a $\$ 1$ contribution costs the corporation $\$ 1$ (1-0.4), or a $\$ 0.60$ net cash outflow, but creates $\$ 1$ of pension assets. The .6:1 relationship is important for the arbitrage proportions between the capital structure and the pension fund -- $\$ 0.60$ change in the capital structure offsets a $\$ 1.00$ change in the pension fund. Assume the transaction below is started with moving pension assets from equities ( $\$ 100$ in the example) and using the proceeds to buy bonds. The change in risk in the pension fund is exactly offset in the capital structure by issuing $\$ 60$ of debt and using the proceeds to repurchase $\$ 60$ of corporate stock, thus: to assess the arbitrage, the transaction is evaluated in terms of risk and return.

Table 2

Capital Structure

Issue (sell) debt (\$60 at 6\%)

Buy outstanding stock (\$60)

\section{Pension Fund}

Buy bonds $(\$ 100)$

Sell equities $(\$ 100)$

\section{Risk}

Reduced risk in the pension fund (increasing a fixed income cash flow in exchange for an equity residual cash flow) offset by increasing the risk in the capital structure (increasing the outflow of fixed debt costs and decreasing the outflow of equity residual costs). In other words, the pension fund increases fixed income cash inflows and the capital structure increases fixed income cash outflows; the pension fund decreases equity inflows and the capital structure decreases equity outflows. In summary, increases in the holding of each security are exactly offset by a short position in that security.

\section{Return}

The arbitrage produces an almost certain increase in cash flows, stemming from tax savings. In the capital structure the corporation receives a tax deduction from the interest payment of $\$ 60 \times 0.06 \times 0.4=\$ 2.40$. Since the payment of dividends is not tax deductible, there is no loss of tax deduction from buying back outstanding stock. And the pension returns are not taxed. Therefore, the firm realizes a net gain of $\$ 2.40$ with no increase in risk. 


\section{COUNTRY ANALYSIS OF THE TAX ARBITRAGE STRATEGY}

The tax arbitrage model was introduced in the U.S. and most of the studies of the market's impounding pension returns have been conducted in the U.S. markets. However, the first public move to an all bond position, based on Black's arbitrage strategy has been in the U.K. market with Boots, Britain's largest retail pharmacy [Gold 2003]. The arbitrage strategy clearly has application outside the U.S. but the question this paper addresses is how widespread is the prospective application and what are the relative benefits in each country.

The developed countries are selected because defined benefit pensions will have had sufficient time to develop into an economic force in the more industrialized countries. From this sample we then address whether the tax arbitrage strategy is viable. If viable, the final step is then to evaluate the impact of implementing the tax arbitrage in the specific countries.

\section{Is Pension Tax Arbitrage Viable?}

To determine viability, the paper asked the following four questions, and based on the answers and investigations, the seven finalists were selected that complied with the four questions asked:

1. Does the country have defined benefit pension plans?

2. $\quad$ Are the plans pre-funded (as opposed to pay as you go)?

3. Are the returns on pension assets exempt from taxation?

4. Does a corporation's payment of interest to creditors have a tax advantage relative to the payment of dividends to shareholders? Here we assume that this is the case.

\section{COUNTRY COMPARISON OF THE BENEFITS}

The data in Table 3 reflect tax rates and interest rates for the selected countries. The tax rates were obtained from KPMG's Corporate Tax Rates Survey with rates effective January 1, 2004 [2004 KPM International]. Because of difficulty in obtaining specifics of tax treatment, the assumption was made that the tax rate for the deduction of pension contributions was equivalent to the tax rate for the interest deduction.

Corporate interest rate data was not readily available in all sample countries. Therefore, a uniform estimation process was applied. The estimation of the corporate rate began with the 10-year rate for the government bonds which were then "grossed up" by the proportionate quality yield spread. For example, the 10-year Brazilian government rate as of March 18, 2005 was 7.875 percent [http://www.bloomberg.com/markets/rates]. The estimated quality spread is derived from the May 17, 2005 U.S. market [http://bonds.yahoo.com/rates.html] where the 10Year S\&P Corporate rate is 4.63 percent and the 10-year Treasury is 4.09 percent. The quality factor, which converts from the government rate to the Corporate rate is therefore $4.63 \% / 4.09 \%=1.132$. This rate then applied to

Table 4 provides a comparative analysis of the selected countries in terms of the annual cash savings from implementation of the pension tax arbitrage strategy. Column 1 provides the percentage to be applied to the dollars of pension assets shifted from stocks to bonds. Column 2 ranks the countries in terms of annual benefit. Column 3 analyses the tax rate impact of the arbitrage model, separate from the interest rate impact.

The annual cash flow benefits are much greater for Brazil than for the other countries. The results are largely driven by high interest rates. Brazil has the highest interest rate and generates the greatest cash flows benefits; Japan has the lowest interest rate and has the smallest cash flow benefits. 
Table 3

Interest Rate And Tax Rate Information

For Pension Arbitrage

\begin{tabular}{cccc}
\hline & Tax Rate on: & Tax Rate on: & \\
\hline Selected & $\begin{array}{c}\text { Corporate } \\
\text { Contribution to } \\
\text { Pension Plan }\end{array}$ & $\begin{array}{c}\text { Interest } \\
\text { Payment }\end{array}$ & $\begin{array}{c}\text { Interest Rate } \\
\text { Investment Grade } \\
\text { Corporate }\end{array}$ \\
\hline Belgium & 0.340 & 0.340 & 0.043 \\
Brazil & 0.340 & 0.340 & 0.089 \\
Canada & 0.366 & 0.366 & 0.048 \\
Denmark & 0.300 & 0.300 & 0.043 \\
Japan & 0.420 & 0.420 & 0.015 \\
Norway & 0.280 & 0.280 & 0.045 \\
UK & 0.300 & 0.300 & 0.054 \\
US & 0.400 & 0.400 & 0.056 \\
\hline
\end{tabular}

Sources for Interest Rates: US, UK, Brazil, Japan http://www.bloomberg.com/markets/rates

Canada http://www.econstats.com/r/rcan_ew3.htm ; Norway http://www.econstats.com/r/rnor_ew3.htm

Belgium and Denmark http://www.ecb.int/stats/money/long/html/index.en.html

All tax rate information was obtained from KPMG International Survey 2004.

Brazilian rate by multiplying the Brazilian government rate by 1.132 to yield an estimate of the Brazilian corporate rate $7.875 \% \mathrm{x}$ $1.132=8.915 \%$.

Table 4

Value Creation From Pension Tax Arbitrage

\begin{tabular}{cccc}
\hline Selected Countries & $\begin{array}{c}\text { Cash Savings From } \\
\text { Reallocation \% } \\
(\mathbf{1})\end{array}$ & Ranking of Savings & Tax Impact \% \\
\hline Belgium & 0.955 & $\mathbf{( 2 )}$ & $\mathbf{( 3 )}$ \\
Brazil & 1.994 & 5 & 22.44 \\
Canada & 1.111 & 4 & 23.44 \\
Denmark & 0.908 & 6 & 21.00 \\
Japan & 0.358 & 8 & 24.36 \\
Norway & 0.901 & 7 & 20.16 \\
U.K. & 1.129 & 3 & 21.00 \\
U.S. & 1.348 & 2 & 24.00 \\
\hline
\end{tabular}

The value creation is based on the model described previously:

Annual Cash Flow Savings $=\{[(1-\mathrm{Tx}) * \mathrm{Tx}] *(\mathrm{I}) * \mathrm{PA}\}$

Where: Tx is the tax rate, $\mathrm{I}$ is the interest rate, PA is the dollar value of pension assets reallocated.

Column (1) is the product of the first 3 terms, $\{[(1-T x)(T x)](I)\}$, yielding the percentage to be applied to the dollar value of pension assets reallocated. And Column (3) is the product of the first two terms, $[(1-T x)(T x)]=\left(T x-T x^{2}\right)$

The impact of the corporate tax rate is surprisingly small because of two offsetting functions. While the corporate tax rate directly increases the tax benefits, it also reduces the proportionate impact of a change in pension assets on capital structure. If, for instance, the tax rate is 40 percent, the net cost of a $\$ 1.00$ contribution to the pension fund is $\$ .60$ to the contributing pension sponsor. Therefore, a change in asset allocation of $\$ 1.00$ of pension assets can be offset by a change in $\$ .60$ in the capital structure. As noted, the tax rate impact $=\left(\mathrm{Tx}-\mathrm{Tx}^{2}\right)$. As a result the tax 
rate impact is a non-linear function of tax rates. The tax impact is the greatest for a tax rate of 50 percent with the impact decreasing as tax rates decrease.

In our model, the interest rates are the dominant factor in value creation. Black's pension tax arbitrage model [Black 1981] employs a different approach. Black capitalizes the cash flows by dividing by the after tax interest rate, or I (1-Tx), resulting in an increase in market value of:

Black's Value Creation $=\frac{\left\{\left[\left(1-T_{x}\right) * T_{x}\right]^{*}(i) * P A\right\}}{i\left(1-T_{x}\right)}=(\mathrm{T} * \mathrm{PA})$

Therefore, for Black's model, the tax rate was the sole determinant. For this study, annual cash flows are deemed a superior measure. The multinational community displays instability of tax rates and regulations which determine if arbitrage conditions apply. Treating the cash flows as perpetuity is inappropriate given such instability.

Overall, the analysis indicates that the tax arbitrage strategy does not apply in many countries. But for those where pension tax arbitrage is viable, the advantages are considerable - yielding an annual cash flow advantage between 90 and 199 basis points, with Japan's low interest rates generating a relatively small cash inflow of only 36 basis points of the pension assets reallocated.

\section{CONCLUSION}

The implementation of the pension tax arbitrage strategy must address the inability of the investing public to see beyond the pension plan itself. Relative to bonds, stocks are a long-term security, with higher expected returns. On its face, stocks seem a superior asset for pensions. But, as has been demonstrated, if the pension fund is seen within the context of the overall firm, investing the pension assets in bonds provides a no-risk method for increasing the rate of return to the firm's shareholders. Perhaps, the greater disclosure of economic information, as required by FAS 132 (revised) and by IAS 19 will provide a greater understanding by the investing public and pave the way for a better understanding of what pension tax arbitrage can accomplish.

The benefits are certainly available, as demonstrated in Table 4. It appears that the annual cash flow from pension arbitrage is greater for countries with higher interest rate levels. The impact of tax rate is surprisingly small because while the corporate tax rate directly increases the tax benefits, it reduces the proportionate impact of a change in pension assets on capital structure. However, the tax impact is the greatest for a tax rate of 50 percent with the impact decreasing as tax rates decrease.

Further research might explore other issues related to the cash flows stemming from tax arbitrage. A major component is the stability of the national regulations regarding defined benefit funds; another area of research involves a more specific analysis of the on-going stability of the tax treatment of interest, dividends, and pension contributions.

\section{APPENDIX A}

\section{France}

Contributions are tax deductible and pensions are taxed as income. Two types of pension contribution plans exist in France. The Public Earnings- Related Pensions are financed by contributions, but government grants variable subsidies. The pension age is 60 for both men and women, but currently a minimum of 40 years contributions is required. Public earnings-related benefits amounted to 72.8 percent of the total old-age benefits. The Public Flat-Rate Pensions comprises both means-tested flat pensions and earning-related pensions. Flat-rate pensions are financed by contributions and state subsidy. The entitlement age is 65 for both males and females. The minimum monthly allowance was E540 (45 percent of the average annual wage in manufacturing), and the means-tested benefits amounted to 3.7 percent of the total old-age benefits. 
The implicit replacement rate or the ratio of average pension to average wage is 56 percent. Pension from private savings and life insurance is voluntary and premiums are partially tax deductible. Mandatory occupational pension schemes are funded on a pay-as-you-go basis (PAYG) plus voluntary capital-funded schemes. PAYG supplementary benefits amounted to 21.7 percent of total old-age benefits [International Reform Monitor 2004].

\section{Italy}

Rarely do employers use pension plan in Italy because the Social Security is so good. Thus, neither defined benefit or contribution would be used. Workers with 35 years on the job can retire if they are at least 57 . For those with less than 35 years of work, the benefit is at a reduced rate (for example, for 31 years of service, the reduced rate is 90 percent of salary). Before a series of changes introduced in 1995, there was no age requirement, and some government workers were eligible to retire after as little as 15 years on the job. These early retirement laws are more lax than in the rest of Europe. According to European Union (EU) statistics, only 28 percent of Italian aged 55-64 works, compared with 38 percent in Germany and an average of 39 percent in the Union [http://www.enepri.org/Paperstrapen/JOHNTURNER.doc, and http://web.lexis-nexis.com/universe/prindoc]. The system is also strained by the special privileges enjoyed by some state workers, like employees of Sicily's regional government who can retire after 25 years on the job if they are male and after 20 years if they are female. Italy's problem is more acute by the fact that only 55 percent of Italian aged 15-64 works, compare with a EU average of 64 percent. Italy's quality of life among the best in the world, its pension system is beginning to feel the effects of accommodating its aging population.

Italy spends around 14 percent of GDP on pensions, one of the highest levels in Europe. The Italian Parliament voted in the late July 2004 to increase the Italian retirement age to 60 and to channel worker unemployment indemnity payments, known as trattamento a fine rapporto (TFR), into pension plans. This legislation has not been written into law. Under the present system, 7 percent of an employee's salary goes into the TFR system. This guarantees a return approximate to inflation and is used by Italian as a safety net in the case of unemployment [http://web.lexis-nexis.com/universe/printdoc].

\section{Germany}

Germany is known as "the country of un-funded pension plans. It is because German tax legislation historically favored defined benefit (DB) pension plan in the form of direct pension commitments. These plans do not require any form of funding at all, but German companies have to show a pension liability in their books. Essentially, pension obligations are funded "internally" by the aggregate of all company assets. A large part of the existing pension liabilities for direct commitments (approximately 40 percent) has been matched with external investments, either in the form of insurance policies or in the form of mixed bond and equity portfolios. However, these are essentially company assets and may be used for other purposes than paying pensions. Like France, Germany companies use pay-as-you-go schemes.

The new German tax legislation in 2001 and 2004 made the German company pension system even more complicated. With the introduction of Pensionsfonds, the employer has a choice of five financing vehicles: direct commitments, support funds, Pensionskassen, Pensionsfonds, and direct insurance contracts. Of course the tax implications are different and vehicles may be reinsured in part or all. Direct commitments and support funds may be funded or un-funded. The employer may also combine some or all of these vehicles in hybrids plans with defined contribution and defined benefit elements which deduct the benefits of one plan from the benefits of other plans in order to make the best use of whole framework.

\section{Sweden}

Sweden has a long tradition of social insurance. Sweden was the first nation to implement a mandatory government retirement system for all citizens. The pension plan consists of National Basic Pension (BP) and National Supplementary Pension (ATM). The old system was a tax-financed, pay-as-you-go entitlement program, similar to the United States' Social Security program. In addition, a second, earnings-related supplementary pension (ATP) was 
available. Similar to the U.S. Social security program, the supplementary pension provided old age benefits linked to each worker's earnings history. Like American system, the Swedish system has a trust fund that is supposed to invest surplus payroll taxes in order to pay benefits when baby-boomer generation retires.

The Swedish pension program faced financial problems similar to the troubles plaguing the U.S. Social Security system, and the Swedes decided in 1998 that partial privatization was the best solution. Now workers must put 18.5 percent of their income aside retirement (split between employer and employee each with 9.25 percent) but they are now able to invest 2.5 percent points of that amount in an individual account. The remaining 16 percent is a tax that funds the pay-as-you-go government program [Heritage Foundation 2000].

\section{Norway}

Private pension plans are common in Norway in addition to the Social Security to bring up the total retirement pension up to a level of 60 percent to 70 percent of pay after 30-40 years' service. Both the Social Security and defined benefit plans have the same retirement provision and policy rules [William M. Mercer Companies LLC 2005].

\section{Finland}

Finland has Social Security (National Pension) as well as defined benefit plans. The Employees' Pension Act was passed in 1961 to supplement the National Pension Plan. The supplementary plan completely funded by the employers, private or public, who paid contributions equal on average to about 10 percent of a worker's earnings, into fund managed by seven large insurance companies or set up funds on their own. Self employed persons had to choose a fund [http://www.country-studies.com/finland/ national-pension-plan.htm].

\section{Netherlands}

The pension system in Netherlands consists of three pillars - basic public pensions, occupational pensions, and individual pensions. The state's basic pension program is a pay-as-you-go program. Under this plan, all residents aged between 15 and 65 are obliged to pay 17.9 percent of their annual income as premiums. The program provides all residents aged 65 and older with a flat rate pension benefit. In addition, many people are covered by nonmandatory occupational pensions formed through collective labor agreements between employees and employers. These pensions are based on a capital funding system, in which premiums are saved up and invested before being paid out. The individual pensions are considered defined benefit and supplemental plan and it is on a voluntary basis. This plan can be a part of the corporate pension plan or private plans [The Japan Times 2004].

\section{Switzerland}

Underlying the Swiss retirement system is the Federal Occupational retirement and Survivors' Insurance Scheme or AHV/AVS. The first-tier social insurance program, established in 1948, provides basic old age and surviving dependants' benefits. This is a program like the programs found in the United States (Social Security) and Canada (Canada Pension Plan) - pay-as-you-go. The supplemental or a second-tier plan is known as BVG, since 1985 , requires that employees contribute to privately administering compulsory occupational schemes. While the BVG system is effectively defined contribution (DC) based, many of the benefits actually paid exceed the minimum requirements and are formulated on a defined benefit (DB) basis. Since 1995, like DB plans in the U.S., accountholders or contributors can withdraw funds from their pension plan to purchase residential property [Heritage Foundation 2000].

\section{South Korea}

South Korea is in the process of transition from old system of pay-as-you-go to a new system by 2006 in which the Korean workers can funnel their retirement funds into security market, and take advantage of economic and market growth, as well as, being responsible for their returns. Government would allow workers to choose between 
defined benefits or defined contribution plans. Brokerage firms, banks, insurance companies and investment trust companies with solid financial records will be allowed to manage the pension funds. A company can choose between existing severance payment system and the new retirement pension plans or offer both [Korea.net 2004].

\section{Endnote}

$\overline{1}$ The accounting continues to be controversial. FAS 87 has been updated with FAS 132. The latest revision of FAS 132 was delayed because of the International Accounting Standard (IAS 19had not completed its ruling on pension accounting.

\section{REFERENCES}

1. A High Quality of Life, A Strained Pension Plan, LexisNexis Academic, The New York Times Company, August 20,2003, http://web.lexis-nexis.com/universe/printdoc.

2. Arita, Eriko, Japan May Go Dutch with Pension Plan, The Japan Times, July 10, 2004, http://202.221.217.59/print/news/nn07-2004/nn20040710fl.htm.

3. A Rare Ottowa Success: The Canadian Pension Plan is one of the Best in the World - and Will Remain Sound, LexisNexis Academic, July 1, 2003, http://web.lexisnexis.com/universe/printdoc.

4. Barth, M. E., W. Beaver, and W. Landsman, 1992. The Market Valuation Implications of Net Periodic Pension Cost Components, Journal of Accounting and Economics, 15 (1992): 27-62.

5. Barth, M. E., W. Beaver, and W. Landsman, The Relevance of The Value Relevance Literature For Financial Accounting Standard Setting: Another View, Journal of Accounting and Economics, 31 (2001) 77-104.

6. Barth, M.E., W.H. Beaver, and M. Wolfson, Relative Measurement Errors Among Alternative Pension Asset and Liability Measures, The Accounting Review, 66 (July 1991): 433-463.

7. Black, F. The Tax Consequences of Long Run Pension Policy, Financial Analysts Journal, (July-August 1980): 21-30.

8. $\quad$ Canada: Private Pensions and Savings, February 2004; www.sdc.gc.ca/asp/gateway.asp?hr=/en/isp/common/ris/privpension.shtml\&hs=cpr\#pps2.

9. Canadian Pension Plan Ontario: Ministry of Agriculture and Food, September 2004, www.gov.on.ca/OMAFRA/english/busdev/facts/01-029.htm.

10. Copeland, T., J. Weston, and K. Shastri, Financial Theory and Corporate Policy, Fourth Edition, Chapter 17, Pearson Addison-Wesley, Boston, MA, 2005, 738-741.

11. Coronado, J.L. and S.A. Sharpe, Did Pension Plan Accounting Contribute to a Stock Market 'Bubble'? Brookings Papers on Economic Activity, March 2003.

12. Daley, L.A., The Valuation of Reported Pension Measures for Firms Sponsoring Defined Benefit Plans, The Accounting Review, 59 (April 1984): 177-98.

13. Dammon, R.M., C.S. Spratt, and H.H. Zhang, Optimal Asset Location and Allocation with Taxable and TaxDeferred Investing, The Journal of Finance, (June 2004): 999-1037.

14. Feldstein, M. and S. Seligman, Pension Funding, Share Prices and National Saving, Journal of Finance, (September 1981):801-824.

15. Financial Accounting Standards Board (FASB), Employers' Accounting for Pensions, Statement of Financial Accounting Standard No. 87, Stamford, CT: FASB.

16. Finland National Pension Plan, February 16, 2005, http://www.countrystudies.com/finland/ national-pension plan.html.

17. Franks, Mary Margaret, The Impact of Taxes on Corporate Defined Benefit Plan Asset Allocation, Journal of Accounting Research, (Volume 40: Issue 4) 2003, pp. 1163-1190.

18. Gold, Jeremy and Nick Hudson, Creating Value in Pension Plans, Journal of Applied Corporate Finance, Fall 2003.

19. Gordon Tim and Stuart Jarvis, Financial Economics and Pension Actuaries: The U.K. Experience, Presented at the Great Controversy: Current Pension Actuarial Practice in Light of Financial Economics Symposium, Sponsored by the Society of Actuaries, Vancouver, June 2003.

20. Harrington, Cynthia, Retirees at Risk, CFA Magazine, January/February 2004.

21. Harris, David O., Switzerland's National Retirement Approach, The Heritage Foundation, February 16, 2005, http://www.heritage.org/Research/Social Security/hl672.cfm. 
22. How European Companies are Applying IAS 19 (revised) on Pension Accounting in the First Year of Application, Federation des Experts Comptables Europeens, October 2001.

23. International Corporate Rates, Office of Tax Policy Research (www.OTPR.org), University of Michigan, http://ww.taxfoundation.org/internationaltax/intcorporates.html, February 15, 2005.

24. Japan Passes Defined Contribution Pension Legislation, Investment Company Institute, Online, July 2001, www. Ici.org/issues/glo/01_japan_pension_leg_final.html.

25. Jin, Li, Robert Morton, and Zoi Bodie, Do a Firm's Equity Returns Reflect the Risk of Its Pension Plans? National Bureau of Economic Research, Working Paper, \# 10650, Cambridge, Mass., August 2004.

26. Landsman, W., An Empirical Investigation of Pension Fund Property Rights, The Accounting Review, 61 (1986): 662-691.

27. Lopes, Mario Dias, Pension Funds in Brazil, March 1999, http://apep.org/international/ braz_emp_p sch.html.

28. mySAP Human Resources, SAP Belgium \& Luxembourg - Pension Plan, 2005; www.sap.com/belux/solutions/business-suite/erp/hcm/belgiumspecific/pensionfunds/-25k.

29. Nelson, Norma, Employers-Sponsored Pension Benefits in Canada, November 4, 1999; www.ucalgary.ca/MG/inrm/finplan/retire/Cnerpens.htm.

30. Normann, Goran and Daniel J. Mitchell, Pension Reform in Sweden: Lessons for American Policymakers, The Heritage Foundation, February 16, 2005, http://www.heritage.org/research/social security/bg1381.cfm.

31. Norway: Benefits and Legislative Update, William M. Mercer Companies LLC, 2005.

32. Oldfield, G. Financial Aspects of the Private Pension System, Journal of Money, Credit and Banking, 9, 1 (June 1977): 48-54.

33. Painful: European Pension Accounting, LexisNexis, November 13, 2004, http://web.lexisnexis.com/universe/document?_m=720ce3510a32c88c4cfa429fc859b6ef.

34. Pension Accounting in Germany, Countdown to IFRS, October 7, 2004, www.mercerhr.com/ summary.jhtml?idContent $=1157675$.

35. Pension Fund Governance in the US and Europe, Centre for Economic Policy Research, the United Kingdom, February 17, 2005, Http://www.cepr.org/DP3955.htm.

36. Pension Provision - France, International Reform Monitor, September 27, 2004, Online, www.reformmonitor.org/httpd-cache/doc_stq_pp-158.html.

37. Sinha, Tapen, The Great Pension Reform: AFOREs and the Future of Privatized Retirement in Mexico, Instituto Technologico Autonomo de Mexico, Texas Business Review, University of Texas at Austin, October, 1998, http://www.utexas.edu/depts./bbr/tbr/Oct.98.Sinha.html.

38. South Korea to Offer Individual Retirement Plan, Korea.net, February 16, 2005, http://korea.net /News/News/newsprint.asp?serial_no=20040823013.

39. Superannuation - for Employees, Australian taxation Office, Australian Government, February 16, 2005, Http://www.ato.gov.au/print.asp?doc=/content/19150.htm.

40. Tepper, Irwin, 1981, Taxation and Corporate Pension Policy, Journal of Finance, 36 (1981): 1-13.

41. Wyatt, Watson, Significant Pension Legislation Coming to Belgium, The Multinational, 2005; www.watsonwyatt.com/multinational/render2.asp?ID=10070-39k.

42. World Corporate Tax Guide, 2002-2004.

43. Yermo, Juan, Recent Developments in Occupational Pension Plan Accounting, OECD, 2003, Juan.Yermo@oecd.org. 
International Business \& Economics Research Journal - April 2007

Volume 6, Number 4

NOTES 